The question of delegates to the General Assembly of the International League against Rheumatism was discussed, and it was decided that the new League should nominate four or five persons who might act as councillors.

It was moved by Prof. Datey (India) and seconded by Dr. Highton (New Zealand) that the new League should apply for affiliation within the constitution of the International League.

It was decided that the dues for the maintenance of this South-East Asia and Pacific Area League against Rheumatism should be $5 s$. sterling per annum per member.
It was decided that the next meeting should be held in India at either Bombay or Delhi in January or February, 1967.

Dr. Engleman suggested that further meetings should be arranged so that they do not conflict with other continental meetings, and it was decided to invite the International League to hold its meeting in Sydney or 1969 or 1973.

Other topics of discussion included participation in the organization for the prevention of rheumatic fever, the exchange of postgraduate students, and visiting lecturers, and the formation of other leagues in non-member nations.

\title{
OBITUARY
}

\section{DOUGLAS HENRY COLLINS 1907-1964}

Professor D. H. Collins, O.B.E., T.D., F.R.C.P., who died suddenly on August 1, 1964, at the age of 57, was a member of the Editorial Committee of this Journal, and this unexpected deprivation of his experience, enthusiasm, and wise advice will leave a gap not easily filled.

Born in 1907, the son of a general practitioner in Ulverston, he loved the Lake District and returned there as often as he could for holidays. He was educated at Rossall and Liverpool University where he qualified M.B., Ch.B., in 1930. After house appointments at the Royal Southern Hospital he started on a distinguished pathological career by holding the Holt Fellowship in Pathology in Liverpool. In 1934 he obtained a rheumatism research fellowship at Leeds University and worked at the Bath Hospital in Harrogate. Among other research projects he studied arthritis in pigs and so began his interest in bone and joint diseases.

In 1936 he worked with Walter Bauer at the Massachusetts General Hospital and during his time in America visited the Mayo Clinic and began a lasting friendship with Philip Hench. He was building a reputation as an expert pathologist in the rheumatic group of diseases, but during the Second World War was asked to establish emergency laboratories in Yorkshire; in 1940 he moved to Sheffield and for a time was superintendent of the emergency hospital at Wharncliffe. Awarded the O.B.E. in

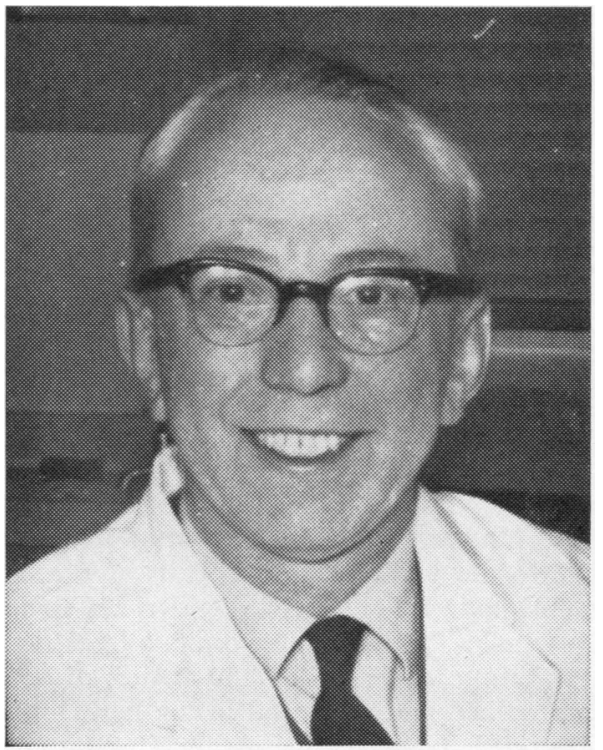

1946, he returned to Leeds as reader in clinical pathology and his main research work from that time was concerned with joint disease. In 1949 he published "The Pathology of Articular and Spinal Diseases", a model of careful pathological description, which achieved immediate recognition, and 
during this time became assistant editor of the Journal of Pathology and Bacteriology.

He returned to Sheffield to take the Joseph Hunter Chair of Pathology in 1959 and thereafter played an increasing part in University affairs. He was a member of the planning committee of the new Sheffield teaching hospital and medical school, had recently joined the Regional Hospital Board, and was Public Orator in the University.

His premature death is a great loss to rheumatism research. Douglas Collins had for many years been unwilling to accept the explanation that osteoarthritis was simply the inevitable result of growing old, and he was investigating the underlying pathology of this condition with financial aid from the Arthritis and Rheumatism Council.

He had bent the technical resources of his department, histochemical, radiochemical, radiological, microscopical, and experimental, towards research into the pathology of bone and joint disease. By means of isotope techniques he was studying the early changes in osteo-arthritis; his investigations into the results of direct injury to joint cartilage showed that there was an increased activity of the cells forming the deeper layers of cartilage and that this was followed by an increase in the output of mucopolysaccharides. Through this work, which was reported on a number of occasions in this Journal, it became clear that the first change leading to osteo-arthritis occurs in the deeper layer of the cartilage or bone and not on the surface as had been supposed. Investigations into the blood supply have revealed that change in the cartilage depends on the vascular activity of the underlying bone.

Through all this work he had built up an excellent research team who must feel keenly the untimely loss of their leader.

His international reputation as an authority on bone and joint disease brought much material to his laboratory and many invitations from overseas; in spite of a serious illness in 1959 he recently undertook a lecture tour in India for the World Health Organization.

Douglas Collins was an accomplished musician and one of the most delightful personalities one could meet. His great charm and infectious cheerfulness earned him a host of friends in many quarters; we offer our sympathy and regrets to his widow and to his son and daughter.

Oswald Savage.

\section{JOSEPH JAY BUNIM, 1906-1964}

On July 8, 1964, Dr. J. J. Bunim died suddenly from a heart attack. His loss will be keenly felt by all rheumatologists in Britain and throughout the world, in a personal as well as in a professional and scientific sense.

Joseph Jay Bunim was born in Wolozin, Russia, in 1906. In early childhood he emigrated with his parents to the United States and became a United States citizen in 1914. His father was a scholar with high principles, his mother a woman of great warmth and capability, and Joe had the virtues of both his parents refined and tempered in the hard school of New York Medicine.

He graduated B.Sc. from the College of the City of New York in 1926 and received his doctorate of medicine in 1930 and a doctorate of science in 1938 from the New York University School of Medicine. He started his medical career with two years of internship and assistant residency on the Third (New York University) Medical Division of Bellevue
Hospital. He was then awarded a research fellowship to spend a year at Yale where work concerned with haemolytic streptococci and rheumatic fever awakened his interest in rheumatic diseases. When he returned to Bellevue to complete his residency he naturally allied himself with the laboratory group which had recently been established at New York Medical School to study rheumatic fever. Subsequently the interests of the group and of Bunim himself widened to embrace the whole field of rheumatic diseases. He served as head of the arthritis clinic of the Third Medical Division of Bellevue Hospital from 1939 to 1952 and was intimately associated with what became the Rheumatic Diseases Study Group after 1945. In the New York University School of Medicine he became associate professor in 1949, and in addition to these important clinical, scientific, and teaching responsibilities he developed a most successful practice in cardiology and rheumatology. All this he left in 